\title{
Effects of Row Pattern, Seeding Rate, and Inoculation Date on Fungicide Efficacy and Development of Peanut Stem Rot
}

\author{
L. E. Sconyers, T. B. Brenneman, and K. L. Stevenson, Department of Plant Pathology, and B. G. Mullinix, Ex- \\ perimental Statistics, University of Georgia Coastal Plain Experiment Station, Tifton 31794
}

\begin{abstract}
Sconyers, L. E., Brenneman, T. B., Stevenson, K. L., and Mullinix, B. G. 2007. Effects of row pattern, seeding rate, and inoculation date on fungicide efficacy and development of peanut stem rot. Plant Dis. 91:273-278.

Two field studies were conducted in 2000, 2001, and 2002 to determine the effects of row pattern (91.4-cm single or 20.3-cm twin) and seeding rate (single: 12.5, 17.4, or 22.6 seed m${ }^{-1}$ or twin: 6.2, 8.9, or 11.5 seed $^{-1}$ ) on peanut stem rot (Sclerotium rolfsii) development. The first study was conducted in a naturally infested field and relative efficacy of azoxystrobin (Abound $2.08 \mathrm{~F}$, applied at a rate of $0.3 \mathrm{~kg}$ a.i. ha $\mathrm{h}^{-1}$ at 60 and 90 days after planting [DAP]) also was evaluated. In this study, stem rot incidence was significantly greater $(P<0.05)$ in single rows planted at high seeding rates than in twin rows planted at any of the seeding rates. Row pattern did not affect azoxystrobin efficacy, and disease incidence was nearly half as much in twin rows treated with fungicide than incidence in single rows treated with fungicide. In the second field study, individual peanut plants in fumigated plots were inoculated once with $S$. rolfsii at 50,70, or 90 DAP. Stem rot incidence at harvest was significantly greater on plants inoculated 50 DAP than plants inoculated 70 or 90 DAP. The incidence of spread to adjacent rows was higher in plots where plants were inoculated at 50 than at 90 DAP. Plants inoculated 90 DAP had less disease at harvest, but often developed more severe symptoms within the first week after inoculation compared with plants inoculated 50 or 70 DAP. Symptoms were more severe in single than in twin rows, and at the higher seeding rates. Data from these studies suggest that the physical spacing between plants is a critical factor in stem rot development both on individual plants and in plant populations.
\end{abstract}

Additional keywords: Arachis hypogaea, twin-row plantings

Tomato spotted wilt (TSW), caused by Tomato spotted wilt virus (TSWV), has been a significant problem for peanut (Arachis hypogaea L.) producers since the early 1990s. In Georgia alone, TSW cost producers an average $\$ 8.2$ million annually (21,32-35). Researchers have found that TSW incidence was lower in high populations of plants planted in conventional single rows, and that planting twin rows $(7.6 \mathrm{~cm}$ apart) and high seeding rates $\left(>13.1 \mathrm{seed} \mathrm{m}^{-1}\right.$ ) could further reduce TSW incidence and increase quality and yield $(13,31)$. From 1995 to 2003, the use of twin-row patterns and higher seeding rates $\left(>112 \mathrm{~kg} \mathrm{ha}^{-1}\right)$ has increased in Georgia (10 to 41 and 30 to $67 \%$, respectively), largely for TSW management $(3,27,28)$. It is not known why these cultural practices help minimize TSW, but it may be due to rapid ground coverage (which may reduce attraction of thrips) or fewer thrips on individual plants in more dense plantings (8).

Corresponding author: L. E. Sconyers

E-mail: 1sconyrs@uga.edu

Accepted for publication 26 September 2006

DOI: 10.1094/PDIS-91-3-0273

(C) 2007 The American Phytopathological Society
Stem rot, caused by Sclerotium rolfsii Sacc., is as damaging as TSW to peanut. In Georgia, stem rot costs farmers an average of $\$ 9.7$ million in damages and $\$ 16.2$ million in control costs annually $(21,32-35)$. S. rolfsii infects over 500 species of plants and causes crown, pod, and stem rot on peanut (1). Fluffy, white mycelium typically is found at the crown of its host; however, this fungus can infect any part of a susceptible host when conditions are conducive $(1,22)$. Optimal mycelial growth of the fungus occurs from 27 to $30^{\circ} \mathrm{C}$ under conditions of high relative humidity and can be extensive depending on soil compaction, soil aeration, nutrient availability, and host availability (1).

Research has been conducted to examine the effect of seeding rate or row pattern on peanut stem rot development in naturally infested fields. Minton and Csinos (19) examined the effect of planting single and twin rows (seed spaced $7.6 \mathrm{~cm}$ apart for single rows and 7.6 and $15.2 \mathrm{~cm}$ apart for twin rows) on stem rot incidence, and found no consistent advantage for any of the treatments in managing this disease. Wehtje et al. (31) found that stem rot incidence increased linearly from 5.0 loci/plot at a seeding rate of $34 \mathrm{~kg} \mathrm{ha}^{-1}$ to 6.7 loci/plot at $124 \mathrm{~kg} \mathrm{ha}^{-1}$ or higher seeding rates in runner-type peanut planted in sin- gle rows; however, TSW incidence decreased with increasing seeding rates. In another study, a reduced seeding rate ( 8 to 12 seed $\mathrm{m}^{-2}$ ) in irrigated 'GK-7' and 'Southern Runner' peanut did not increase the incidence of TSW, and also helped to manage stem rot as well as rust (5). The mechanism for the decrease in stem rot with lower seeding rates is unclear, but it may be due to less plant-to-plant spread. In all studies reported to date, researchers have examined either seeding rate or row pattern effects, but the interactive effects of seeding rate and row pattern, particularly with controlled inoculations, have not been investigated.

Modification of seeding rate has some effect on stem rot development; however, management in the field relies primarily on rotation and fungicides. Until 1994, stem rot of peanut was managed using granular products including pentachloronitrobenzene (PCNB) and chloropyrifos (Lorsban) (14). However, these pesticides provided only about 20 to $60 \%$ control of stem rot $(11,30)$ and growers found the return on investment to be marginal (11). Today, there are more effective fungicides for stem rot control, such as azoxystrobin (Abound), tebuconazole (Folicur), and flutolanil (Moncut) $(6,10)$. These products are applied by spraying on the foliage of the plants, an application strategy generally thought best suited for foliar diseases. Studies with dye have since shown foliar applications to be very effective at delivering fungicides to key infection courts where fungicide protection is most needed, such as the crown and pegs of peanut plants (12). Changing row pattern and seeding rate can alter peanut growth (16); however, it is not known whether these changes affect fungicide deposition or subsequent redistribution and efficacy. Deposition within the peanut canopy may be influenced by the volume of water used during application, with lower volumes resulting in a more layered distribution of very high concentrations on the upper leaves and very low concentrations near the soil (7). The interactive effects of row pattern, seeding rate, and fungicide efficacy on peanut stem rot development have not been reported.

The objectives of this study were to examine the effects of seeding rate and row pattern on stem rot progression in the field on individual plants and plant populations exposed to either natural inoculum or sin- 
gle plant inoculations, and to determine if these planting patterns affect fungicide efficacy. A preliminary report of portions of this work has been published (24).

\section{MATERIALS AND METHODS}

Two field studies were conducted each year from 2000 to 2002, all planted with certified 'Georgia Green' peanut seed treated with captan (45\% a.i.), PCNB (15\% a.i.), and carboxin (10\% a.i.) (Vitavax PC, Gustafson LLC, Plano, TX) at $2.49 \mathrm{~g} \mathrm{~kg}^{-1}$ of seed. Both studies were planted 17 May, 20 May, and 22 May in 2000, 2001, and 2002, respectively. Plots (7.5 m long) were planted on a $91.4-\mathrm{cm}$ wide bed in either single rows $(91.4 \mathrm{~cm}$ apart) or twin rows $(91.4 \mathrm{~cm}$ between outer

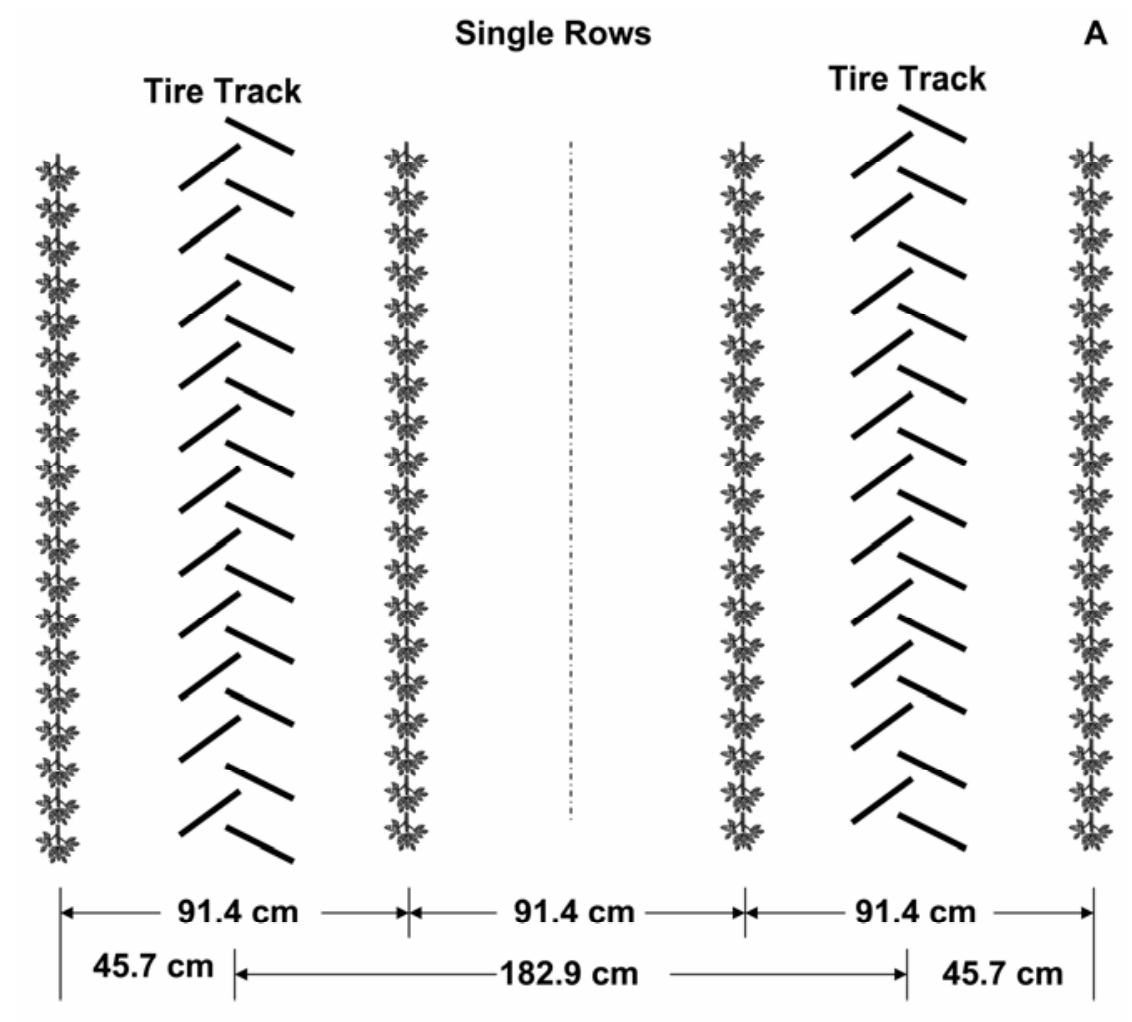

A

Twin Rows

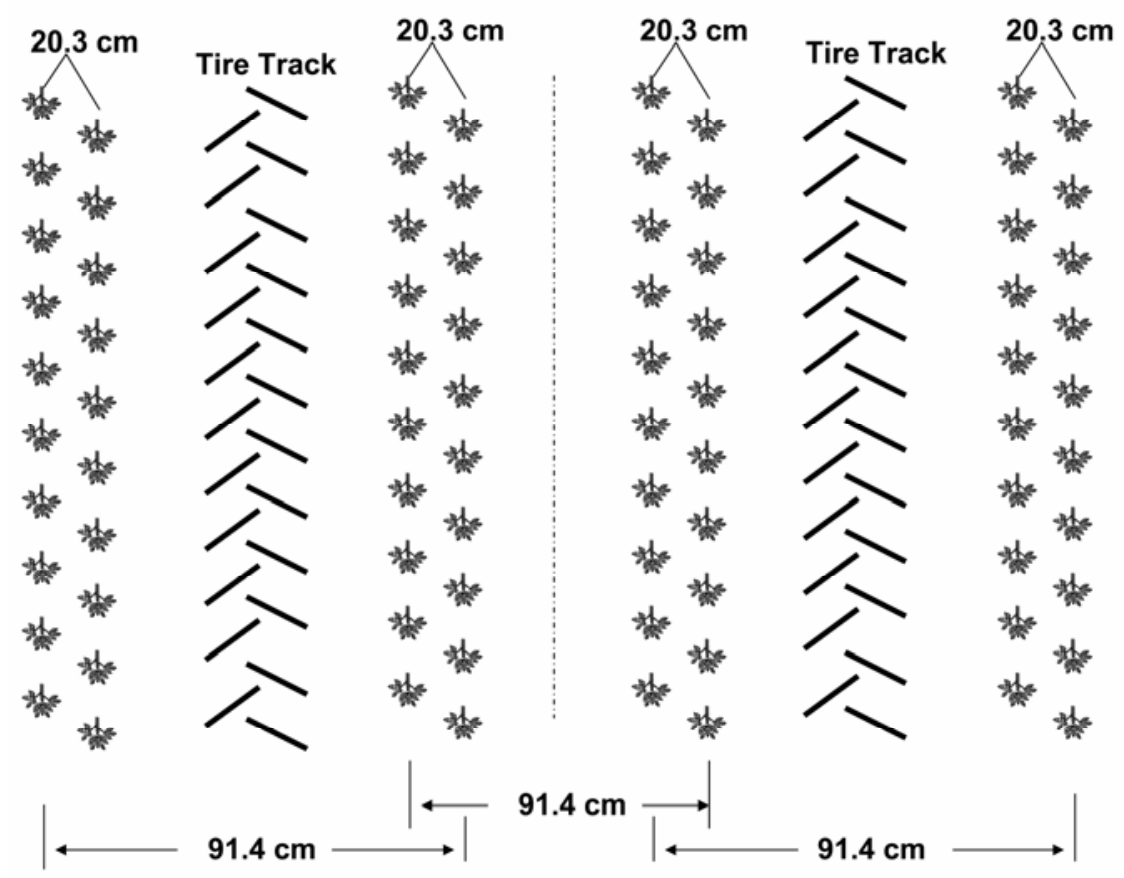

Fig. 1. Aerial representation of $\mathbf{A}$, the single-row pattern (rows $91.4 \mathrm{~cm}$ apart) and $\mathbf{B}$, the twin-row pattern ( $91.4 \mathrm{~cm}$ between outer rows and $20.3 \mathrm{~cm}$ between twin rows) in peanut field plots. Diagrams not drawn to scale. rows, $20.3 \mathrm{~cm}$ between twins) (Fig. 1) with Monosem Vacuum Planters (ATI Inc., Lenexa, KS) at low, medium, or high seeding rates of $12.5,17.4$, or 22.6 seed $\mathrm{m}^{-1}$ for

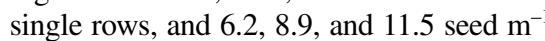
for each twin row. Seeding rates were chosen to obtain similar total plant populations in plots at each seeding rate (low, medium, and high), regardless of row pattern. Hereafter, seeding rates will be referred to as low, medium, and high. Both studies were designed as randomized complete block factorial experiments with four replicates. Fallow alleys ( $2.4 \mathrm{~m}$ wide) between plots were included to reduce positive interplot interference. Phorate (Thimet 20 G; BASF Ag Products, Research Triangle Park, NC) was applied at a rate of 1.12 $\mathrm{kg}$ a.i. ha $\mathrm{h}^{-1}$ in-furrow at planting to reduce thrips damage and TSW.

Field study 1. The first study was planted in a Fuquay loamy sand (88\% sand, $9 \%$ silt, $3 \%$ clay, and 2 to $5 \%$ slope) in a field with a history of stem rot and continuous peanut production for 3 to 4 years prior to this study. Chlorothalonil (Bravo Ultrex; Syngenta Crop Protection, Greensboro, NC) was applied to all plots at a rate of $1.57 \mathrm{~kg} \mathrm{ha}^{-1}$ on a 14-day schedule to control foliar fungal pathogens that may interfere with stem rot development. Weeds and insects were managed according to conventional practices specified by the University of Georgia Cooperative Extension Service (4). Plots either were treated with azoxystrobin (Abound $2.08 \mathrm{~F}$; Syngenta Crop Protection, Greensboro, $\mathrm{NC})$ at a rate of $0.3 \mathrm{~kg} \mathrm{ha}^{-1}$ at 60 and 90 days after planting (DAP) to control stem rot, or not treated with fungicide. The fungicide was applied with a $\mathrm{CO}_{2}$-pressurized belt-pack sprayer using a 2-liter bottle and a 190 liter ha ${ }^{-1}$ broadcast boom with three Conjet TX-SS6 hollow cone nozzles (Spraying Systems Co., Wheaton, IL) per row at 40 psi.

Stem rot incidence was assessed after the first fungicide application and after digging by counting the number of 30.5$\mathrm{cm}$ row lengths per plot showing stem rot signs and symptoms, dividing that number by the total number of $30.5-\mathrm{cm}$ row lengths per plot, and multiplying by 100 . TSW incidence was assessed in a similar manner at 57 DAP and after digging. All plots were dug mechanically and inverted with a KMC digger/inverter (Kelley Mfg. Co., Tifton, GA) 149, 137, and 160 DAP in 2000, 2001, and 2002, respectively. Windrows were mechanically harvested with a two-row combine in 2000, 2001, and 2002 at 154,149 , and 179 DAP, respectively. Pods were dried to about $10 \%$ moisture and graded according to standard United States Department of Agriculture procedures (2).

Data were analyzed by analysis of variance with the SAS PROC GLM (SAS Institute Inc., Cary, NC) procedure to determine the effects of year, row pattern, 
seeding rate, and fungicide treatment on stem rot incidence, yield, and pod grade. Treatment means were compared using Fisher's least significant difference test. The level of significance for all comparisons was $5 \%$.

Field study 2. The second experiment included the same planting patterns as the first study but was planted in a field of Tifton loamy sand ( 2 to $5 \%$ slope) that was tarped and fumigated with a methyl bromide-chloropicrin mixture applied at a rate of $450 \mathrm{~kg} \mathrm{ha}^{-1}(67 \%$ methyl bromide a.i. and 33\% chloropicrin a.i.) prior to planting each year to virtually eliminate populations of $S$. rolfsii. The objective of this study was to compare the effects of row spacing, seeding rate, and fungicide on stem rot epidemics initiated at known times during the season.

Individual plants at $1.5-\mathrm{m}$ intervals within the rows of each plot were marked with a 76.2-cm wire flag for a total of eight flagged plants per plot. Prior to inoculation, plots were treated with acephate insecticide (Orthene 75S, Valent Agricultural Products, Germantown, TN) at a rate of $1.1 \mathrm{~kg}$ a.i./ha to prevent imported red fire ants (Solenopsis invicta Buren) from eating the agar plugs. Isolate SR-8 of Sclerotium rolfsii, originally isolated from peanut, was grown and maintained on potato dextrose agar at approximately $24^{\circ} \mathrm{C}$. Flagged plants for each plot were inoculated once at 50, 70 , or 90 DAP with a 1-cm-diameter hyphal plug taken from the edge of an actively growing colony and placed at the soil line with the mycelium against the base of the main stem. Plots were irrigated $(1.3 \mathrm{~cm} /$ day $)$ via overhead irrigation for three consecutive days following each inoculation to promote infection and disease development.

Stem rot severity of each inoculated plant was assessed after digging each year using a modified version of a severity scale created by Shokes (26), where $0=$ no disease, $1=0$ to $5,2=5$ to $25,3=25$ to $50 \%$, $4=50$ to 75 , and $5=75$ to $100 \%$ disease.
Severity values were converted back to a percentage scale based on the midpoint of each severity class interval prior to statistical analysis. Stem rot incidence was determined by counting all plants per plot showing signs and symptoms, dividing by the total plant count per plot, and multiplying by 100 . Disease spread along rows was assessed by measuring the length (in centimeters) of each inoculated disease focus. Cumulative spread per plot then was obtained by summing the lengths of all eight foci per plot. The incidence of disease spread across rows also was determined based on the percentage of the eight inoculated foci per plot that spread to the adjacent twin row. An initial rate of infection, expressed as plants per day, was estimated 7 days after each inoculation as the total number of plants showing visible signs of the pathogen divided by 7 days. All plots were harvested, dried, and graded according to methods mentioned previously for field study 1 .

Data were analyzed by analysis of variance with SAS PROC GLM procedure to determine the effects of year, row pattern, seeding rate, and inoculation date on stem rot severity, incidence, spread, yield, and grade quality. Treatment means were compared using Fisher's least significant difference test $(P<0.05)$.

\section{RESULTS}

Field study 1. Although all 3 years were somewhat dry, combined rainfall and irrigation during the growing season was over $50 \mathrm{~cm}$ each year, and sufficient for stem rot development. Due to significant interactions with year, data for stem rot incidence after the first fungicide application was analyzed separately by year (Table 1). There was a significant year-row patternfungicide interaction on the incidence of stem rot assessed after the first fungicide application. Disease levels were highest in 2000 , and there was a significant difference between single and twin nontreated plots (Table 1). Azoxystrobin prevented stem rot development in both single and twin rows, and there was no difference between single and twin plots treated with fungicide. In 2001 and 2002, overall disease incidence was low (0.2 to $4.2 \%)$, and there were no significant differences between row patterns or fungicide treatments.

There was a significant year-seeding rate-fungicide interaction effect on the incidence of stem rot after the first fungicide application. In 2000, stem rot incidence was greater in the nontreated, highseeding-rate plots than the nontreated medium- or low-seeding-rate plots. There was no significant difference in stem rot incidence among seeding rates when treated with azoxystrobin. Incidence of stem rot was greater in nontreated plots than in treated plots except at the low seeding rate (Table 1). In 2001 and 2002, stem rot incidence was much lower ( 0.4 to $4.5 \%)$ than incidence in 2000 , and there were no significant differences among the three seeding rates or between treated and nontreated plots in either year (data not shown).

There was a significant row patternseeding rate interaction effect on stem rot incidence after digging (Table 1), but there were no interactions with year, allowing the 3 years of data to be combined. In single rows, stem rot was significantly greater at the high seeding rate compared with the medium or low rates (Table 1). Disease incidence also was significantly greater in the single-row pattern compared with the twin-row pattern regardless of seeding rate across all years. There was no significant difference between seeding rates planted in a twin-row pattern.

There was a significant year-row pattern interaction effect on spotted wilt incidence at 57 DAP (Table 2). In 2000, spotted wilt incidence was higher in single rows $(3.1 \%)$ than in twin rows $(0.9 \%)$. However, in 2001 and 2002, there were no differences in spotted wilt incidence between single and twin rows. Seeding rate had no effect on spotted wilt incidence at 57 DAP in any

Table 1. Influence of seeding rate, row pattern, and fungicide treatment on stem rot incidence after the first fungicide application and after digging in 2000, 2001, and 2002 in a peanut field naturally infested with Sclerotium rolfsii

\begin{tabular}{|c|c|c|c|c|c|c|c|c|}
\hline \multirow[b]{4}{*}{ Pattern, rate $^{\mathrm{z}}$} & \multicolumn{8}{|c|}{ Stem rot incidence after ${ }^{y}$} \\
\hline & \multicolumn{6}{|c|}{ First fungicide application (\%) } & & \\
\hline & \multicolumn{2}{|c|}{2000} & \multicolumn{2}{|c|}{2001} & \multicolumn{2}{|c|}{2002} & \multicolumn{2}{|c|}{ Digging (\%) } \\
\hline & Nontreated & Treated & Nontreated & Treated & Nontreated & Treated & Single & Twin \\
\hline \multicolumn{9}{|l|}{ Row pattern } \\
\hline Single & $15.8 \mathrm{a}^{*}$ & $4.7 \mathrm{a}^{*}$ & $3.1 \mathrm{a}$ & $2.6 \mathrm{a}$ & $2.5 \mathrm{a}$ & $4.2 \mathrm{a}$ & $\ldots$ & $\ldots$ \\
\hline Twin & $6.1 \mathrm{~b}^{*}$ & $1.8 \mathrm{a}^{*}$ & $0.2 \mathrm{a}$ & $0.3 \mathrm{a}$ & $4.1 \mathrm{a}$ & $2.6 \mathrm{a}$ & $\ldots$ & $\ldots$ \\
\hline \multicolumn{9}{|l|}{ Seeding rate } \\
\hline Low & $8.4 \mathrm{~b}$ & $4.4 \mathrm{a}$ & $0.4 \mathrm{a}$ & $0.6 \mathrm{a}$ & $4.3 \mathrm{a}$ & $4.5 \mathrm{a}$ & $13.6 b^{*}$ & $5.4 \mathrm{a}^{*}$ \\
\hline Medium & $8.4 b^{*}$ & $1.5 \mathrm{a}^{*}$ & $1.6 \mathrm{a}$ & $1.9 \mathrm{a}$ & $2.8 \mathrm{a}$ & $2.5 \mathrm{a}$ & $16.5 b^{*}$ & $5.9 \mathrm{a}^{*}$ \\
\hline High & $16.1 \mathrm{a}^{*}$ & $3.8 \mathrm{a}^{*}$ & $2.9 \mathrm{a}$ & $1.9 \mathrm{a}$ & $2.9 \mathrm{a}$ & $3.1 \mathrm{a}$ & $21.3 \mathrm{a}^{*}$ & $5.4 \mathrm{a}^{*}$ \\
\hline
\end{tabular}

y Stem rot incidence was determined by counting the number of 30.5-cm row lengths per plot showing signs and symptoms of stem rot and spotted wilt, dividing by the total number of $30.5-\mathrm{cm}$ row lengths per plot, and multiplying by 100 . Plots were either treated with azoxystrobin (Abound $2.08 \mathrm{~F}$, $0.3 \mathrm{~kg}$ a.i. ha ${ }^{-1}$ at 60 and 90 DAP) or were not treated. Means not followed by a common letter within each column and means followed by an asterisk within each row and year are significantly different $(P<0.05)$ according to Fisher's least significant difference $t$ test.

${ }^{z}$ Plots were planted in either single $(91.4 \mathrm{~cm}$ apart) or twin rows ( $91.4 \mathrm{~cm}$ between outer rows, $20.3 \mathrm{~cm}$ between twin rows). Plots were planted at low, medium, or high seeding rates of $12.5,17.4$, or 22.6 seed $\mathrm{m}^{-1}$ for single-row plots and $6.2,8.9$, and $11.5 \mathrm{seed}^{-1}$ for twin-row plots. 
year. There was a significant year-row pattern interaction effect on spotted wilt incidence after digging (Table 2). In 2000, spotted wilt incidence was significantly higher in single rows $(16.2 \%)$ than in twin rows $(6.0 \%)$. In 2001 and 2002, disease levels were much lower and there were no differences in spotted wilt incidence between single and twin rows (Table 2). Seeding rate had no effect on spotted wilt incidence after digging in any year.

There were significant seeding rate, row pattern, and fungicide treatment main effects on yield in field study 1, and there were no significant interactions (Table 3). Yield was significantly greater in plots planted at the high seeding rate than in those planted at the low, but not the medium, seeding rate. Yield was significantly greater in twin rows $\left(3,113 \mathrm{~kg} \mathrm{ha}^{-1}\right)$ than in single rows $\left(2,540 \mathrm{~kg} \mathrm{ha}^{-1}\right)$ and in plots treated with azoxystrobin $\left(3,054 \mathrm{~kg} \mathrm{ha}^{-1}\right)$ than in nontreated plots $\left(2,599 \mathrm{~kg} \mathrm{ha}^{-1}\right)$.

Evaluation of quality of peanut yields (data not shown) showed a significant year-row pattern-seeding rate interaction effect on the percentage of foreign material, but differences were small and no plot yield had more than $0.7 \%$ foreign material. The mean percentage of immature kernels was significantly higher in single rows $(10.6 \%)$ than in twin rows $(9.8 \%)$. There were more immature kernels in 2001 than 2002 and, in 2001, there were more immature kernels in the low seeding rate $(17.0 \%)$ than in the medium rate $(14.9 \%)$. There were no significant differences in quality among seeding rates in 2002. The percentage of sound mature kernels and sound splits (\%SMKSS) across all years was significantly greater in the medium seeding rate $(64.8 \%)$ than the low seeding rate $(61.9 \%)$ only. The mean percentage of damaged kernels was 1.2 and $2.9 \%$ in 2001 and 2002, respectively, and was not significantly affected by row pattern or seeding rate. Some insecticide or herbicide injury occurred, which delayed maturity and lowered grades.

Field study 2. There was a significant main effect of seeding rate on stem rot severity on inoculated plants after digging; severity was greater on inoculated plants at the high seeding rate $(41.7 \%)$ than at the low $(33.5 \%)$ or medium rates $(36.8 \%)$. There was also a year-row pattern interaction effect. In 2000 and 2001, there was no significant difference between the single and twin-row pattern; however, in 2002, disease severity of individual inoculated plants was greatest in the single-row pattern $(60.7 \%)$ and almost double that of the twin-row pattern (32.8\%).

There was a significant row patternseeding rate interaction effect on stem rot incidence after digging (Table 4). Stem rot incidence was significantly greater in single rows compared with twin rows at all seeding rates. In twin rows, there was no significant difference among different seeding rates; however, in single rows, more diseased plants were observed at high seeding rates than at a low seeding rate. There was also a significant inoculation date main effect on stem rot incidence per plot (data not shown). Stem rot incidence was significantly greater in plots inoculated at 50 DAP (24\%) than 90 DAP (19\%).

There was a significant row patternseeding rate interaction effect on cumulative stem rot spread along rows after digging (Table 4). Cumulative spread along rows was significantly greater in single rows planted at a high seeding rate than in those planted at a low seeding rate. In twin rows, there was no significant difference in disease spread among any of the seeding rates.

There was an inoculation date-row pattern interaction effect on the frequency of spread from inoculated foci to adjacent rows within each plot. Spread in twin rows was greater in plots inoculated at 50 DAP $(15.3 \%)$ than in those inoculated at 90 DAP $(7.3 \%)$, with 70-DAP inoculations being intermediate $(11.8 \%)$. No spread across single rows was observed in any year.

There was a significant year-row pattern by inoculation date effect on the initial infection rate determined 7 days after each inoculation date (Table 5). Seeding rate had no effect on the infection rate in any

Table 2. Influence of row pattern on spotted wilt incidence 57 days after planting (DAP) and after digging in 2000, 2001, and 2002 in a peanut field naturally infested with Sclerotium rolfsii

\begin{tabular}{lccccccc}
\hline & \multicolumn{5}{c}{ Spotted wilt incidence $^{\mathrm{y}}$} \\
\cline { 2 - 4 } \cline { 7 - 9 } Row pattern $^{\mathbf{z}}$ & $\mathbf{3 0 0 0}$ & $\mathbf{2 0 0 1}$ & $\mathbf{2 0 0 2}$ & & $\mathbf{2 0 0 0}$ & $\mathbf{2 0 0 1}$ & $\mathbf{2 0 0 2}$ \\
\hline Single & $3.1 \mathrm{a}$ & $0.4 \mathrm{a}$ & $3.3 \mathrm{a}$ & & $16.2 \mathrm{a}$ & $0.8 \mathrm{a}$ & $6.5 \mathrm{a}$ \\
Twin & $0.9 \mathrm{~b}$ & $0.3 \mathrm{a}$ & $2.1 \mathrm{a}$ & & $6.0 \mathrm{~b}$ & $0.7 \mathrm{a}$ & $2.6 \mathrm{a}$ \\
\hline
\end{tabular}

y All plots were mechanically dug and inverted with a KMC digger/inverter (Kelley Mfg. Co., Tifton, GA) 149, 137, and 160 DAP in 2000, 2001, and 2002, respectively. Spotted wilt incidence was determined by counting the number of $30.5-\mathrm{cm}$ row lengths per plot showing signs and symptoms of stem rot and spotted wilt, dividing by the total number of $30.5-\mathrm{cm}$ row lengths per plot, and multiplying by 100. Means not followed by a common letter within each column, and means followed by an asterisk within each row and row pattern, are significantly different $(P<0.05)$ according to Fisher's least significant difference $t$ test.

${ }^{\mathrm{z}}$ Plots were planted in either single $(91.4 \mathrm{~cm}$ apart) or twin rows $(91.4 \mathrm{~cm}$ between outer rows, 20.3 $\mathrm{cm}$ between twin rows). year. In 2000, the infection rate in singlerow plots (2.3 plants per day) was significantly greater for plots inoculated at 90 DAP than the plots inoculated at 70 or 50 DAP. In twin rows, the initial infection rate was significantly greater following the 90 DAP inoculation than the 50-DAP inoculation only. In 2001 and 2002, the 90-DAP inoculation had a significantly greater infection rate (1.1 plants/day) than the 50DAP inoculation (0.8 plants/day).

The only factor with a significant effect on yield in field study 2 was row pattern in both 2001 and 2002. There were no differences among seeding rates or inoculation dates. Mean pod yield in twin rows was $5,469 \mathrm{~kg} \mathrm{ha}^{-1}$ versus $5,159 \mathrm{~kg} \mathrm{ha}^{-1}$ in single rows. The higher yields recorded in twin rows in these findings are consistent with results from previous studies (3). Evaluation of yield quality indicated a significant year-row pattern interaction for percentage of foreign material, but all were very low $(<0.6 \%)$ and, therefore, of no economic significance (data not shown). Only seeding rate had a significant effect on the percentage of immature kernels, which were significantly greater in the low seeding rate $(10.2 \%)$ compared with the high seeding rate $(9.1 \%)$. There was a significant year-row pattern interaction and a significant seeding rate main effect on \%SMKSS. \%SMKSS was significantly greater in twin rows $(67.9 \%)$ than in single rows $(66.0 \%)$ in 2002 , but there was no difference in \%SMKSS between row patterns in 2001 (61.1 and 62.1\%). The high seeding rate $(64.8 \%)$ had significantly greater \%SMKSS than the low seeding rate $(63.5 \%)$ across all years.

Table 3. Influence of seeding rate, row pattern, and fungicide treatment on yield $\left(\mathrm{kg} \mathrm{ha}^{-1}\right)$ in 2000,2001 , and 2002 in a peanut field naturally infested with Sclerotium rolfsii

\begin{tabular}{|c|c|}
\hline Variables & Yield $\left(\mathrm{kg} \mathrm{ha}^{-1}\right)^{\mathrm{w}}$ \\
\hline \multicolumn{2}{|c|}{ Seeding rate ${ }^{\mathrm{x}}$} \\
\hline Low & $2,591 \mathrm{~b}$ \\
\hline Medium & $2,881 \mathrm{ab}$ \\
\hline High & $3,007 \mathrm{a}$ \\
\hline \multicolumn{2}{|c|}{ Row pattern ${ }^{y}$} \\
\hline Single & $2,540 \mathrm{~b}$ \\
\hline Twin & 3,113 a \\
\hline \multicolumn{2}{|c|}{ Fungicide treatment ${ }^{z}$} \\
\hline Untreated & $2,599 \mathrm{~b}$ \\
\hline Treated & $3,054 \mathrm{a}$ \\
\hline \multicolumn{2}{|c|}{$\begin{array}{l}{ }^{\text {w}} \text { Means not followed by a common letter within } \\
\text { each column are significantly different }(P< \\
0.05) \text { according to Fisher's least significant } \\
\text { difference } t \text { test. }\end{array}$} \\
\hline \multicolumn{2}{|c|}{$\begin{array}{l}\times \text { Plots were planted at low, medium, or high } \\
\text { seeding rates of } 12.5,17.4 \text {, or } 22.6 \text { seed } \mathrm{m}^{-1} \\
\text { for single-row plots and } 6.2,8.9 \text {, and } 11.5 \text { seed } \\
\mathrm{m}^{-1} \text { for twin-row plots. }\end{array}$} \\
\hline \multicolumn{2}{|c|}{$\begin{array}{l}\text { y Plots were planted in either single }(91.4 \mathrm{~cm} \\
\text { apart) or twin rows }(91.4 \mathrm{~cm} \text { between outer } \\
\text { rows, } 20.3 \mathrm{~cm} \text { between twin rows). }\end{array}$} \\
\hline \multicolumn{2}{|c|}{$\begin{array}{l}\text { z Plots were either treated with azoxystrobin } \\
\text { (Abound } 2.08 \mathrm{~F}, 0.3 \mathrm{~kg} \text { a.i. } \mathrm{ha}^{-1} \text { at } 60 \text { and } 90\end{array}$} \\
\hline
\end{tabular}

DAP) or were not treated. 


\section{DISCUSSION}

Higher seeding rates and a single-row pattern resulted in greater incidence of stem rot in nontreated plots both early and of low disease pressure. Similar trends were found in inoculated plots (field study 2 ), and were evident in both disease severity and degree of spread to other plants. The total epidemic duration also was important because disease spread across rows occurred in twin-row plots with early inoculation dates approximately twice as often as the last inoculation date. Disease incidence after digging also was greater in plots inoculated at 50 DAP than 70 or 90 DAP, but the differences were relatively small and did not affect yield. This may be due in part to the fact that epidemics initiated later in the season can develop more rapidly, which was observed in field study 2 and previous studies (25), and underscores the importance of stem rot control during this part of the growing season.

Based on these results, stem rot can be reduced by planting lower seeding rates in twin rows without compromising TSW management. This was verified by the significantly higher yields in twin versus single rows and also by the disease and late in the growing season, except in years

yield results in the controlled inoculation study. Despite the higher stem rot incidence at the high seeding rate, yield was still greater at that seeding rate in the first experiment, perhaps due to the confounding effects of spotted wilt infections or other factors influencing crop potential. As mentioned earlier, concern about losses to TSW have been largely responsible for the shift to twin rows and higher seeding rates. The availability of new cultivars with much better resistance to TSW should enable growers to lower seeding rates, thereby reducing input costs and the severity of stem rot. Further cost savings may be possible by reducing fungicide inputs in fields with lower risk levels of soilborne disease, due to lower seeding rates, twinrow plantings, or other practices (36). The results of this work demonstrate similar fungicide efficacy across row patterns and seeding rates.

Numerous studies have been conducted to investigate the effect of row pattern, seeding rate, or both on other diseases and hosts. Increased seeding rates have been shown to increase disease on onion (18), snap bean (29), sorghum (20), soybean (15), strawberry (17), and wheat (9), whereas modifying seeding rate or row

Table 4. Influence of seeding rate and row pattern on stem rot incidence and spread after digging in 2000, 2001, and 2002 in a peanut field where individual plants were inoculated with Sclerotium rolfsii at 50,70, and 90 days after planting (DAP) ${ }^{\mathrm{w}}$

\begin{tabular}{llllcc}
\hline & \multicolumn{2}{c}{ Stem rot incidence $(\%)^{\mathbf{x}}$} & & \multicolumn{2}{c}{ Stem rot spread along rows $(\mathbf{c m})^{\mathbf{y}}$} \\
\cline { 2 - 3 } \cline { 5 - 6 } Seeding rate & Single & Twin & & Single & Twin \\
\hline Low & $17.3 \mathrm{~b}^{*}$ & $8.8 \mathrm{a}^{*}$ & & $208.2 \mathrm{~b}^{*}$ & $169.0 \mathrm{a}^{*}$ \\
Medium & $20.4 \mathrm{ab}^{*}$ & $8.0 \mathrm{a}^{*}$ & & $234.7 \mathrm{ab}^{*}$ & $169.1 \mathrm{a}^{*}$ \\
High & $24.1 \mathrm{a}^{*}$ & $7.7 \mathrm{a}^{*}$ & & $268.7 \mathrm{a}^{*}$ & $182.4 \mathrm{a}^{*}$ \\
\hline
\end{tabular}

${ }^{w}$ All plots were mechanically dug and inverted with a KMC digger/inverter (Kelley Mfg. Co., Tifton, GA) 149, 137, and 160 DAP in 2000, 2001, and 2002, respectively. For inoculation, at 50, 70, or 90 DAP, 1-cm-diameter hyphal plugs of $S$. rolfsii were placed against the base of the main stem of 8 flagged plants per plot. Plots were planted in either single $(91.4 \mathrm{~cm}$ apart $)$ or twin rows $(91.4 \mathrm{~cm}$ between outer rows, $20.3 \mathrm{~cm}$ between twin rows). Means not followed by a common letter within each column, and means followed by an asterisk within each row and row pattern, are significantly different $(P<0.05)$ according to Fisher's least significant difference $t$ test.

${ }^{x}$ Stem rot incidence was determined after digging by counting the number of $30.5-\mathrm{cm}$ row lengths per plot showing signs and symptoms of stem rot, dividing by the total number of $30.5-\mathrm{cm}$ row lengths per plot, and multiplying by 100 .

y Cumulative stem rot spread within each plot was obtained by measuring the length $(\mathrm{cm})$ of each inoculated disease focus and summing the lengths of all eight foci per plot.

${ }^{\mathrm{z}}$ Plots were planted at low, medium or high seeding rates of $12.5,17.4$, or $22.6 \mathrm{seed} \mathrm{m}^{-1}$ for singlerow plots, and $6.2,8.9$, and 11.5 seed $\mathrm{m}^{-1}$ for twin-row plots.

Table 5. Influence of inoculation date and row pattern on initial rate of stem rot infection (plants colonized per day) in 2000, 2001, and 2002 in peanut field plots where individual plants were inoculated with Sclerotium rolfsii at 50, 70, and 90 days after planting (DAP) ${ }^{\mathrm{y}}$

\begin{tabular}{|c|c|c|c|c|c|c|}
\hline \multirow[b]{2}{*}{$\mathbf{D A P}^{\mathbf{z}}$} & \multicolumn{2}{|c|}{2000} & \multicolumn{2}{|c|}{2001} & \multicolumn{2}{|c|}{2002} \\
\hline & Single & Twin & Single & Twin & Single & Twin \\
\hline 50 & $0.9 \mathrm{~b}$ & $0.9 \mathrm{~b}$ & $0.8 \mathrm{~b}$ & $0.8 \mathrm{~b}$ & $0.8 \mathrm{~b}$ & $0.8 \mathrm{~b}$ \\
\hline 70 & $1.1 \mathrm{~b}$ & $1.1 \mathrm{ab}$ & $1.2 \mathrm{a}$ & $1.1 \mathrm{a}$ & $0.9 \mathrm{ab}$ & $1.1 \mathrm{a}$ \\
\hline 90 & $2.3 \mathrm{a}^{*}$ & $1.2 \mathrm{a}^{*}$ & $1.1 \mathrm{a}$ & $1.1 \mathrm{a}$ & $1.1 \mathrm{a}$ & $1.1 \mathrm{a}$ \\
\hline
\end{tabular}

${ }^{\mathrm{y}}$ Plots were planted in either single $(91.4 \mathrm{~cm}$ apart) or twin rows $(91.4 \mathrm{~cm}$ between outer rows, 20.3 $\mathrm{cm}$ between twin rows). Means (calculated over all seeding rates) that are followed by a common letter within each column, and means followed by an asterisk within each year and row pattern, are significantly different $(P<0.05)$ according to Fisher's least significant difference $t$ test. Infection rate was determined 7 days after inoculation.

${ }^{\mathrm{z}}$ Inoculation date: at 50,70, or 90 DAP, 1-cm-diameter hyphal plugs of $S$. rolfsii were placed against the base of the main stem of eight flagged plants per plot. pattern has not been useful in reducing disease on upright bean (23). The reasons why changing seeding rates or modifying row patterns affect disease development have been largely speculative. Differences may be due to changes in environmental conditions within the canopy or even susceptibility of individual plants to infection. In this study, symptoms or signs developed more quickly on plants inoculated later in the year when the canopy was more fully developed than on those inoculated earlier. The effect of peanut plant density on susceptibility of individual plants to $S$. rolfsii is unknown, and environmental data (hourly temperature and humidity) collected during this study were inconclusive. It is also apparent that planting single rows and a higher seeding rate results in more closely spaced plants that can serve as a living bridge for mycelial growth. Other factors may be involved, and future studies may result in a better understanding of the factors in this response.

\section{ACKNOWLEDGMENTS}

We thank J. Mixon, P. Hilton, L. MacDonald, L. Mullis, D. Hickey, and U. Hargett for their technical assistance with this study.

\section{LITERATURE CITED}

1. Aycock, R. 1966. Stem rot and other diseases caused by Sclerotium rolfsii. N. C. Agric. Exp. Stn. Tech. Bull. 174. North Carolina State University, Raleigh.

2. Bader, M. J. 1995. Peanut grading. Univ. Ga. Coop. Ext. Serv. Bull. 1123.

3. Baldwin, J. A., Todd, J. W., Weeks, J. R., Gorbet, D. W., Culbreath, A. K., Luke-Morgan, A. S., Fletcher, S. M., and Brown, S. L. 2001 A regional study to evaluate tillage, row patterns, in-furrow insecticide, and planting date on the yield, grade, and tomato spotted wilt virus incidence of the Georgia Green peanut cultivar. Proc. 24th Annu. South. Conserv. Tillage Conf. Sustainable Agric. Oklahoma City, Oklahoma.

4. Beasley, J. P., Jr., Baldwin, J. A., Brown, S. L., Brown, S. M., Padgett, B., Bader, M. J., and Shurley, D. 1997. Georgia peanut production guide. Univ. Ga. Coop. Ext. Serv. Guide Agron. 95-001.

5. Black, M. C., Tewolde, H., Fernandez, C. J., and Schubert, A. M. 2001. Seeding rate, irrigation, and cultivar effects on tomato spotted wilt, rust, and southern blight diseases of peanut. Peanut Sci. 28:1-4.

6. Brenneman, T. B., Murphy, A. P., and Csinos, A. S. 1991. Activity of tebuconazole on Scle rotium rolfsii and Rhizoctonia solani, two soilborne pathogens of peanut. Plant Dis. 75:744747.

7. Brenneman, T. B., Sumner, H. R., and Harrison, G. W. 1990. Deposition and retention of chlorothalonil applied to peanut foliage: effects of application methods, fungicide formulations and oil additives. Peanut Sci. 17:80-84.

8. Brown, S. L., Culbreath, A. K., Todd, J. W., Gorbet, D. W., Baldwin, J. A., and Beasley, J. P., Jr. 2005. Development of a method of risk assessment to facilitate integrated management of spotted wilt of peanut. Plant Dis. 89:348356.

9. Cook, J. R., Ownley, B. H., Zhang, H., and Vakoch, D. 2000. Influence of paired-row spacing and fertilizer placement on yield and root diseases of direct-seeded wheat. Crop Sci. 40:1079-1087.

10. Csinos, A. S. 1987. Control of southern stem 
rot and Rhizoctonia limb rot of peanut with flutolanil. Peanut Sci. 14:55-58.

11. Csinos, A. S., Bell, D. K., Minton, N. A, and Well, H. D. 1983. Evaluation of Trichoderma spp., fungicides and chemical combinations for control of southern stem rot of peanuts. Peanut Sci. 10:75-79.

12. Csinos, A. S., and Kvien, C. S. 1988. Deposition of sprays on the soil for soil-borne targets of peanut. (Abstr.) Proc. Am. Peanut Res. Educ. Soc. Meet. 20:34.

13. Culbreath, A. K., Todd, J. W., and Brown, S. L. 2003. Epidemiology and management of tomato spotted wilt in peanut. Annu. Rev. Phytopathol. 41:53-75.

14. Hagan, A. K., Weeks, J. R., and Bowen, K. 1991. Effects of application timing and method on control of southern stem rot of peanut with foliar-applied fungicides. Peanut Sci. 18:4750.

15. Joye, G. F., Berggren, G. T., and Berner, D. K. 1990. Effects of row spacing and within-row plant population on Rhizoctonia aerial blight of soybean and soybean yield. Plant Dis. 74:158-160.

16. Kvien, C. S., and Bergmark, C. L. 1987. Growth and development of the Florunner peanut cultivar as influenced by population, planting date and water availability. Peanut Sci. 14:11-16.

17. Legard, D. E., Xiao, C. L., Mertely, J. C., and Chandler, C. K. 2000. Effects of plant spacing and cultivar on incidence of Botrytis fruit rot in annual strawberry. Plant Dis. 84:531538

18. Littley, E. R., and Rahe, J. E. 1987. Effect of host plant density on white rot of onion caused by Sclerotium cepivorum. Can. J. Plant Pathol. 9:146-151.

19. Minton, N. A., and Csinos, A. S. 1986. Effects of row spacings and seeding rates of peanut on nematodes and incidence of southern stem rot. Nematropica 16:167-176

20. Pande, S., Mughogho, L. K., Seetharama, N., and Karunakar, R. I. 1989. Effects of nitrogen, plant density, moisture stress and artificial inoculation with Macrophomina phaseolina on charcoal rot incidence in grain sorghum. J. Phytopathol. (Berlin) 126:343-352.

21. Pierce, M. 2004. Georgia plant disease loss estimates. Coop. Ext. Ser. Bull. 41-07, University of Georgia, Athens.

22. Punja, Z. K. 1985. The biology, ecology, and control of Sclerotium rolfsii. Annu. Rev. Phytopathol. 23:97-127.

23. Saindon, G., Huang, H. C., Kozub, G. C., Mundel, H. H, and Kemp, G. A. 1993. Incidence of white mold and yield of upright bean grown in different planting patterns. J. Phytopathol. (Berlin) 137:118-124.

24. Sconyers, L. E., Brenneman, T. B., and Stevenson, K. L. 2002. Effects of seeding rate, row pattern, and fungicide treatment on incidence of peanut stem rot. (Abstr.) Phytopathology 92:S74.

25. Sconyers, L. E., Brenneman, T. B., Stevenson, K. L., and Mullinix, B. G. 2005. Effects of plant spacing, inoculation date, and peanut cultivar on epidemics of peanut stem rot and tomato spotted wilt. Plant Dis. 89:969-974.

26. Shokes, F. M., Weber, Z., Gorbet, D. W., Pudelko, H. A., and Taczanowski, M. 1998. Evaluation of peanut genotypes for resistance to southern stem rot using an agar disk tech- nique. Peanut Sci. 25:12-17.

27. Smith, N. 1995. 1995 Peanut production survey for Georgia. University of Georgia Cooperative Extension Service Agricultural Economics Survey, Tifton.

28. Smith, N. 2003. 2003 Peanut production survey for Georgia. University of Georgia Cooperative Extension Service Agricultural Economics Survey, Tifton.

29. Stevenson, W. R., James, R. V., and Rand, R. E. 2002. Practical alternatives for controlling white mold in snap bean production. (Abstr.) Phytopathology 92:S105.

30. Thompson, S. S. 1978. Control of southern stem rot of peanuts with PCNB plus fensulfothion. Peanut Sci. 5:49-52.

31. Wehtje, G., Weeks, R., West, M., Wells, L., and Pace, P. 1994. Influence of planter type and seeding rate on yield and disease incidence in peanut. Peanut Sci. 21:16-19.

32. Williams-Woodward, J. 2000. Georgia plant disease loss estimates. Coop. Ext. Ser. Bull 41-03, University of Georgia, Athens.

33. Williams-Woodward, J. 2001. Georgia plant disease loss estimates. Coop. Ext. Ser. Bull 41-04, University of Georgia, Athens.

34. Williams-Woodward, J. 2002. Georgia plant disease loss estimates. Coop. Ext. Ser. Bull. 41-05, University of Georgia, Athens.

35. Williams-Woodward, J. 2003. Georgia plant disease loss estimates. Coop. Ext. Ser. Bull 41-06, University of Georgia, Athens.

36. Woodward, J. E., Brenneman, T. B., Kemerait R. C., Jr., and Culbreath, A. K. 2005. Using integrated disease management data to validate a risk index for southern stem rot. (Abstr.) Proc. Am. Peanut Res. Ed. Soc. 37:35-36. 